УДК 634.3:631.543

DOI https://doi.org/10.32848/agrar.innov.2021.8.11

\title{
ДОСВІД ВИКОРИСТАННЯ РІЗНИХ СУБСТРАТІВ ДЛЯ УКОРІНЕННЯ ЖИВЦІВ ЦИТРУСОВИХ КУЛЬТУР
}

\author{
ОМЕЛЯНОВА В.Ю. - асистент кафедри лісового та садово-паркового господарства \\ https://orcid.org/0000-0002-5687-3412 \\ Херсонський державний аграрно-економічний університет \\ КОТОВСЬКА Ю.С. - асистент кафедри лісового та садово-паркового господарства \\ https://orcid.org/0000-0001-7935-209 \\ Херсонський державний аграрно-економічний університет
}

Постановка проблеми. У відкритому ґрунті нашого регіону цитрусові культури не вирощуються через несприятливі кліматичні умови, але переробка їхніх плодів на соки та дитяче харчування існує майже на всіх підприємствах харчової промисловості, що виробляють ці продукти.

До України привозять мандарини й апельсини так званих «технічних» сортів. Плоди на рослинах таких сортів швидко дозрівають, на дереві їх зростає багато, проте вони мають не дуже високі смакові показники. Плоди більш дорогих сортів цитрусових до нас не завозять, бо це економічно не вигідно: зріють довше, загальна кількість їх невелика, а ось за ціною вони набагато дорожчі.

Нині виведені сорти цитрусових культур, наприклад, лимон сорту Київський із високими смаковими якостями, пристосований до вегетації у наших кліматичних умовах, який вивів київський селекціонер Анатолій Патій. Тож дослідження особливостей розмноження та вирощування цитрусових культур в умовах закритого грунту має велике значення для популяризації цих культур серед населення.

Аналіз останніх досліджень і публікацій. Дослідження, проведені науковцем Б. С. Єрмаковим, показали, що здатність живців тієї ж породи вкорінюватися, змінюється в широкому діапазоні. Живці, взяті з дуже молодих пагонів, не можуть закладати й утворювати зачатки коріння. До того ж недозрілі молоді пагони легко загнивають. Занадто здерев'янілі пагони теж не годяться. Хоча більшість із них вкорінюється, але вони утворюють дуже слабку кореневу систему й погано перезимовують. Непридатні для розмноження також черешки із квітковими бруньками, тому що замість приросту розвиваються квітки [4].

Для розмноження живцями цитрусових рослин С.А. Вдовенко, І.Л. Гаврись, О.О. Полутін беруть молоді та доспілі пагони товщиною біля основи не менше 4-5 мм. Живці нарізають 10-12 см довжиною з 4-5 бруньками. На пагоні залишають два верхніх листка, укорочених на третину, нижні видаляють разом із черешками. Укорінюють у чистому річковому піску, який насипають шаром 5 см зверху на пухкий поживний ґрунт товщиною $15 \mathrm{~cm}$. Грунтосуміш готують із 1 частини дернової землі, 1 частини лісового ґрунту, 1 частини перегною і 1 частини річкового піску. Висаджують живці в субстрат на глибину 2 см із площею живлення $10 \times 5$ см. Для прискорення кореневого утворення перед висадкою живці ставлять нижніми зрізами в розчин індолилмасляної кислоти в концентрації 100 мг/л на 20 годин або в розчин коренеутворювача Helprost фірми БТУ-центр. Після вкорінення живців через кожні 10 діб проводять підживлення 0,5\% розчином калійної солі та суперфоссрату, а також $0,3 \%$ розчином сечовини. Відносна вологість повітря має бути 95-100\%, тому весь процес укорінення зазвичай відбувається в теплиці [3; 5].

Постановка завдання. Мета дослідження - проведення дослідів з укорінення живців різних видів цитрусових культур на різних субстратах, аналіз результатів проведених досліджень та надання рекомендацій.

Виклад основного матеріалу.

Одним із способів розмноження цитрусових є живцювання. Впродовж нашого дослідження (2019-2020рр.) таким способом розмножували лимони, мандарини та апельсини. Дослідження із живцювання представників цитрусових культур проводилися на базі приватного тепличного господарства села Раденськ Олешківського району Херсонської області.

Живці брали від здорової рослини, яка вже плодоносила, віком 5-10 років (рис. 1а). Живець був з 2-3 розвиненими бруньками і довжиною близько 8-10 см, на живці 1-3-річного віку було 2-3 листка (рис. 1б). Нижній зріз робили косим, верхній (у разі розрізання живця на декілька частин) - округлим. Живцювання проводили навесні (квітень-травень). Живці вкорінювали в теплицях.

Укорінення проходило за температури повітря $20-24^{\circ} \mathrm{C}$, температури грунту $18-24^{\circ} \mathrm{C}$ і вологості повітря 95-100\%. Протягом 2-3 тижнів з'явилися перші корінці, а повне вкорінення відбулося на 4-6 тиждень. У горщик діаметром 9 см садили по 4-5 живців.

Для досліду використовували торф, пісок, кокосовий субстрат, вермикуліт, торф + пісок, кокосовий субстрат + вермикуліт.

Горщик заповнювали на третину дренажем (керамзит), на який насипали ґрунтову суміш. Грунт злегка змочували водою кімнатної температури. Перед посадкою живці нижнім кінцем занурювали в розчин гетероауксину (або іншого стимулятора росту для укорінення). Після цього заглиблювали живець у підготовлений субстрат на 3-4 см. Грунт у горщику ущільнювали і поливали. Для забезпечення живцям більшої вологості накривали поліетиленовою плівкою. Горщики ставили в тепле місце за температури $20-24^{\circ} \mathrm{C}$ на розсіяне сонячне світло. 
Ознакою вкорінення живців служила поява нових листків і корінців. Акліматизацію вкорінених рослин проводили поетапно: зранку піднімали укриття спочатку на 2-3 години, потім - на 3-4 години. Через 2-3 тижні укриття зняли повністю.

Рентабельність обрання ґрунту відіграє важливу роль під час живцювання рослин, тому одним із головних завдань нашого дослідження було провести порівняльний аналіз укорінення живців цитрусових на різних субстратах. Для дослідів використовувалися живці лимону сорту «Павловський», мандарину сорту «Ковано-Васьо» та апельсину сорту «Вашингтон Навел».

Перший експеримент був закладений у 2019 році, а другий - для порівняння у 2020 році [1; 2]. Результати дослідження були наведені в таблиці 1.

Отже, за результатами проведеного дослідження з укорінення живців цитрусових отримані такі результати: найвищий відсоток приживлюваності лимону сорту «Павлівський», апельсину сорту «Вашингтон Навел» та мандарину сорту «Кавано-Васьо» відбувся
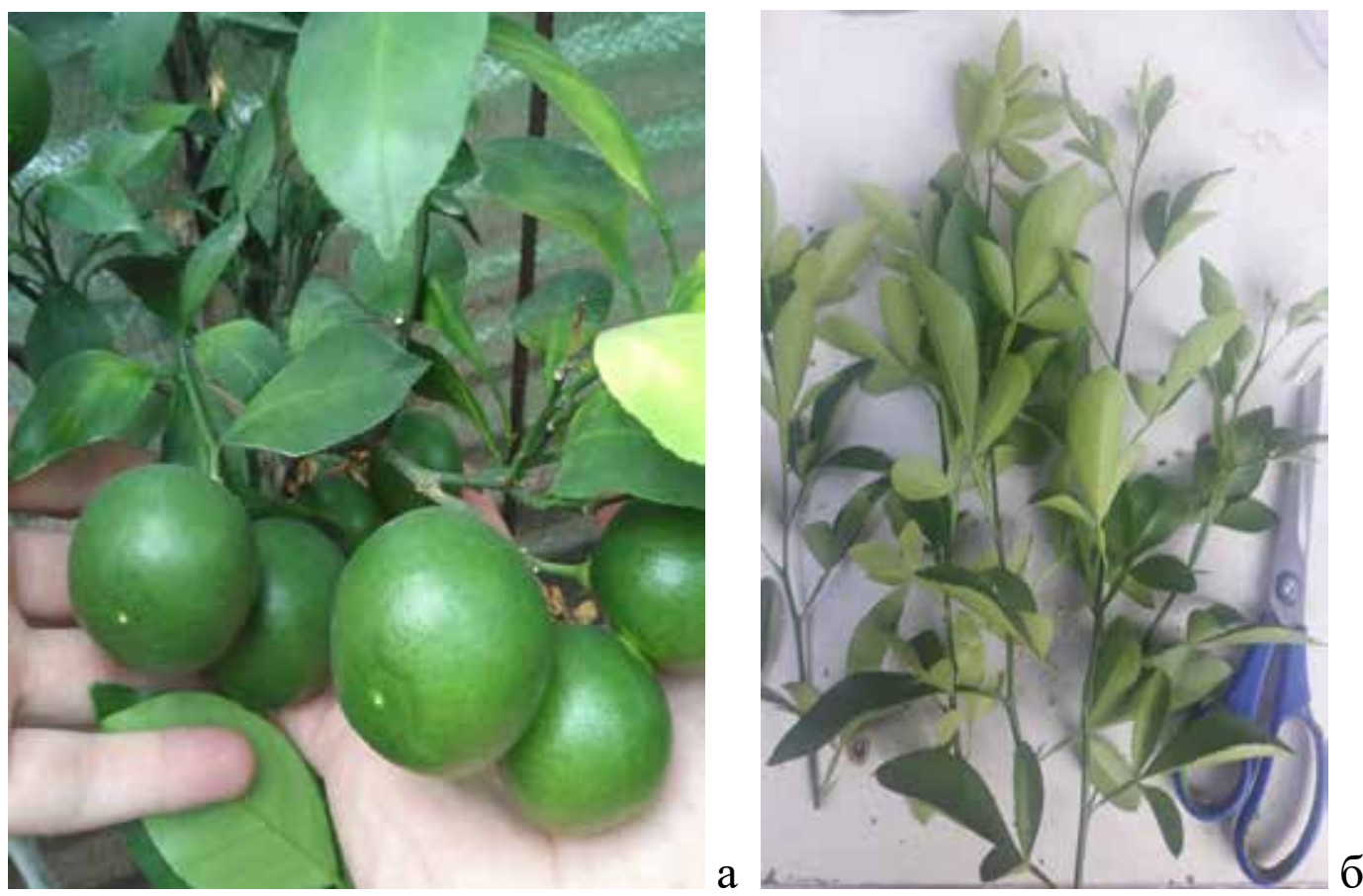

Рис. 1. Лимон: а - материнська рослина, б - заготівля живців

Таблиця 1

Укорінення живців лимону сорту « «Павловський», апельсину сорту «Вашингтон Навел» та мандарину сорту «Ковано-Васьо» на різних субстратах

\begin{tabular}{|c|c|c|c|c|}
\hline \multirow{2}{*}{ Назва } & \multirow{2}{*}{ Субстрат } & \multirow{2}{*}{ шт. } & 2019 рік & 2020 рік \\
\hline & & & $\%$ & $\%$ \\
\hline \multirow{6}{*}{$\begin{array}{l}\text { Citrus limon } \\
\text { ‘Павловський’ }\end{array}$} & торфр & 100 & $22 \%$ & $21 \%$ \\
\hline & пісок & 100 & $43 \%$ & $43 \%$ \\
\hline & кокосовий субстрат & 100 & $81 \%$ & $84 \%$ \\
\hline & вермикуліт & 100 & $92 \%$ & $96 \%$ \\
\hline & торфр + пісок & 100 & $37 \%$ & $39 \%$ \\
\hline & кокосовий субстрат + вермикуліт & 100 & $95 \%$ & $98 \%$ \\
\hline \multirow{6}{*}{$\begin{array}{l}\text { Citrus sinensis 'Вашингтон } \\
\text { Навел' }\end{array}$} & торфр & 100 & $12 \%$ & $12 \%$ \\
\hline & пісок & 100 & $33 \%$ & $33 \%$ \\
\hline & кокосовий субстрат & 100 & $71 \%$ & $71 \%$ \\
\hline & вермикуліт & 100 & $84 \%$ & $82 \%$ \\
\hline & торфр + пісок & 100 & $21 \%$ & $27 \%$ \\
\hline & кокосовий субстрат + вермикуліт & 100 & $86 \%$ & $86 \%$ \\
\hline \multirow{6}{*}{$\begin{array}{l}\text { Citrus reticulata } \\
\text { ‘Ковано-Васьо’ }\end{array}$} & торфр & 100 & $12 \%$ & $13 \%$ \\
\hline & пісок & 100 & $21 \%$ & $26 \%$ \\
\hline & кокосовий субстрат & 100 & $73 \%$ & $73 \%$ \\
\hline & вермикуліт & 100 & $85 \%$ & $84 \%$ \\
\hline & торфр + пісок & 100 & $17 \%$ & $17 \%$ \\
\hline & кокосовий субстрат + вермикуліт & 100 & $88 \%$ & $85 \%$ \\
\hline
\end{tabular}


за наявності кокосового субстрату з додаванням вермикуліту (85-98\%) (рис. 2).

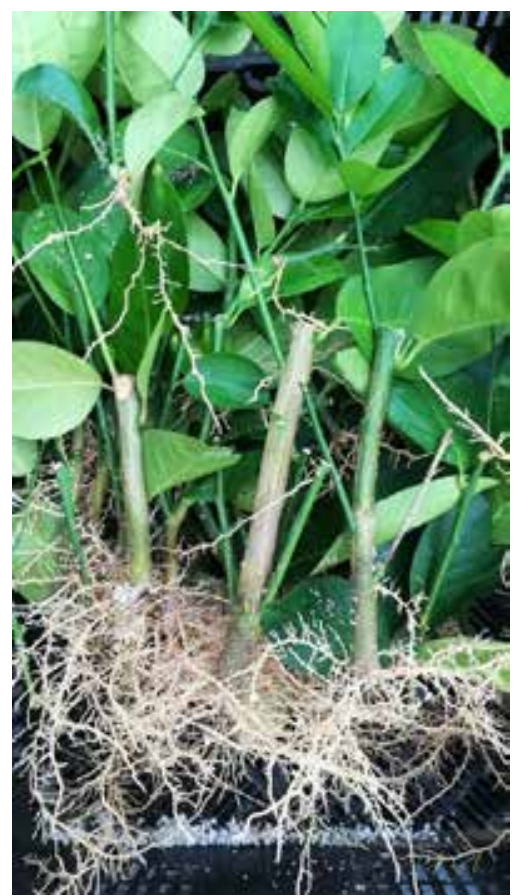

Рис. 2. Живці, що вкорінювалися на кокосовому субстраті з додаванням вермикуліту

Друге місце посідає чистий вермикуліт із відсотком приживлюваності 82-92\%, третє - чистий кокосовий субстрат (81-83\%). Приживлюваність живців на суміші торфу та піску становила 37-39\%, трохи вищою вона була за вирощування на чистому піску (42-45\%). Найменший відсоток приживлюваності рослин спостерігали за вирощування на торфі - 12-22\% (рис. 3).

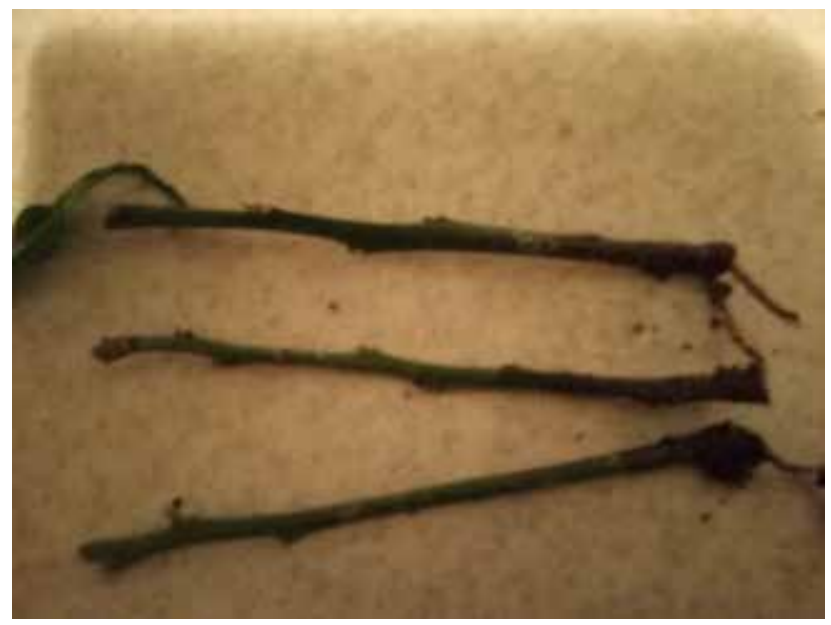

Рис. 3. Живці, що вкорінювалися на торфі

Висновки і пропозиції. Природно-кліматичні умови Херсонської області несприятливі для вирощування цитрусових рослин у відкритому ґрунті. Взимку морози згубно діють на рослини субтропічного походження. Несприятливим $€$ також і режим зволоження. Однак високі харчові, лікарські та декоративні властивості цитрусових рослин зумовили інтерес науковців та аматорів до вирощування їх у закритому ґрунті, оранжереях та в кімнатних умовах.

Порівняно зі щепленням живцювання має низку важливих переваг, головною з яких є розвиток укоріненого цитруса в повній відповідності з біологічними особливостями конкретного сорту. До таких особливостей відносяться розміри, форма і смакові якості плодів, особливості будови листка, а також розміри, форма й характер росту крони деревця, скорочення строків вегетації до повного плодоношення рослини.

Найвищий відсоток приживлюваності лимону сорту «Павлівський», апельсину сорту «Вашингтон Навел» та мандарину сорту «Кавано-Васьо» відмічений у кокосовому субстраті з додаванням вермикуліту (85-98\%).

Для промислового розмноження цитрусових культур бажано використовувати вермікуліт і суміш кокосового субстрату з ним.

\section{СПИСОК ВИКОРИСТАНИХ ДЖЕРЕЛ:}

1. Набока О. М., Бойко Т. О., Котовська Ю. С. Особливості живцювання та вкорінення цитрусових культур в умовах закритого ґрунту. Modalități conceptuale de dezvoltare a științei moderne: colecție de lucrări științifice «^ОГО $\Sigma$ » cu materiale conferinței științifice și practice internaționale, 20 noiembrie 2020. Bucureşti, România: Platforma europeană a științei, 2020. Vol. 1. Pp. 85-88.

2. Набока О. М., Назаренко С. В. Захист лимонів закритого ґрунту від шкідників та хвороб. Наукові читання імені В. М. Виноградова: II-га Всеукраїнська науково-практична конференція. м. Херсон, 21-22 травня 2020 року. Херсон, 2020. С. 41-43.

3. Слєпцов Ю. В., Якубенко Б. Д., Богданова В. Д., Позднков І. О., Андрусик Р. В. Квітникарство закритого ґрунту: навчальний посібник. Київ : КондорВидавництво, 2015. 174 с.

4. Зелене живцювання - метод прискореного розмноження. URL: https://matricja-budovi.at.ua/news/ zelene_zhivcjuvannja_metod_priskorenogo rozmnozhennja/2011-02-11-195 (дата звернення 25.03.2021)

5. Вдовенко С. А., Гаврись І. Л., Полутін О. О. Субтропічні і рідкісні плодоовочеві рослини: навч. посіб. Вінниця : ТОВ «ТВОРИ», 2020. 252 c.

\section{REFERENCES:}

1. Naboka, O.M., Boyko, T.O., Kotovs'ka, Yu.S. (2020). Osoblyvosti zhyvtsyuvannya ta vkorinennya tsytrusovykh kul'tur v umovakh zakrytoho gruntu [Features of grafting and rooting of citrus crops in closed soil]. Modalități conceptuale de dezvoltare a științei moderne: colecție de lucrări științifice «^ОГО $\Sigma$ » cu materiale conferinței științifice și practice internaționale, 20 noiembrie 2020. Bucureşti, România: Platforma europeană a științei, Vol. 1. Pp. 85-88 [in Ukrainian].

2. Naboka, O.M., Nazarenko, S.V. (2020). Zakhyst lymoniv zakrytoho gruntu vid shkidnykiv ta khvorob [Protection of indoor lemons from pests and diseases]. Naukovi chytannya imeni V. M. Vynohradova: II-ha Vseukrayins'ka naukovopraktychna konferentsiya. Kherson, 41-43 [in Ukrainian]. 
3. Slyeptsov, Yu.V., Yakubenko, B.D., Bohdanova, V.D., Pozdnkov, I.O., \& Andrusyk, R.V. (2015). Kvitnykarstvo zakrytoho gruntu [Andrusyk RV Floriculture of closed soil]. Kyyiv : Kondor-Vydavnytstvo, 174 [in Ukrainian].

4. Zelene zhyvtsyuvannya - metod pryskorenoho rozmnozhennya [Green cuttings - a method of accelerated reproduction]. URL: https://matricja-budovi.at.ua/news/ zelene_zhivcjuvannja_metod_priskorenogo_rozmnozhennja/2011-02-11-195 [in Ukrainian].

5. Vdovenko, S.A., Havrys', I.L., Polutin, O.O. (2020). Subtropichni i ridkisni plodoovochevi roslyny [Subtropical and rare fruit and vegetable plants]. Vinnytsya: TOV «TVORY», 252 [in Ukrainian].

Омелянова В.Ю., Котовська Ю.С. Досвід використання різних субстратів для укорінення живців цитрусових культур

Серед численних плодів екзотичних рослин, які $\epsilon$ у вільному доступі, особливою популярністю користуються цитрусові. Плоди мандаринів, апельсинів, лимонів, лаймів, цитронів, грейпфрутів, бергамоту відрізняються високими поживними, лікувальними й дієтичними властивостями. Вони служать сировиною для отримання соків, компотів, цукатів і джемів, цінних ефірних олій і різних есенцій, які широко використовуються в харчовій, кондитерській і парфумерній промисловості. Мета. Нині цитрусові рослини переважно використовуються для кімнатного та офісного озеленення, зимових садів та оранжерей в якості декоративних, а не плодових рослин. Для розвитку виробництва з вирощування цитрусових культур в якості плодових у промислових обсягах необхідний якісний і доступний посадковий матеріал у великих кількостях. Мета дослідження аналіз таких доступних субстратів для живцювання цитрусових культур, як торф, пісок, кокосовий субстрат, вермикуліт, торф із додаванням піску, кокосовий субстрат із додаванням вермикуліту для укорінення живців цитрусових рослин у захищеному ґрунті. Методи. Для отримання посадкового матеріалу використовували метод розмноження цитрусових рослин зеленими живцями в умовах захищеного грунту. Результати. За результатами проведеного дослідження 3 укорінення живців цитрусових культур установлено, що найвищий відсоток приживлюваності лимону сорту «Павлівський», апельсину сорту «Вашингтон Навел» та мандарину сорту «Кавано-Васьо» спостерігався за вирощування рослин у кокосовому субстраті 3 додаванням вермикуліту (85-98\%). Посадковий матеріал, отриманий методом зеленого живцювання за використання кокосового субстрату з додаванням вермикуліту та окремо вермикуліту в тепличному господарстві села Раденськ Олешківського району Херсонської області, показав високий результат вкорінення і приживлюваності порівняно із торфом і піском. Висновки. Проведені дослідження дозволяють рекомендувати для живцювання субстрат із кокосової маси з додаванням вермикуліту та вермикуліт для захищеного грунту та подальшого використання у виробництві цитрусових культур.

Ключові слова: вирощування, цитрусові рослини, захищений ґрунт, сорти, зелене живцювання.

Omelyanova V.Yu., Kotovska Yu.S. Experience in using different substrates for rooting citrus cuttings

Among the many fruits of exotic plants that are freely available, citrus fruits are especially popular. The fruits of tangerines, oranges, lemons, limes, lemons, grapefruits, bergamot have high nutritional, medicinal and dietary properties. They are used as raw materials for juices, compotes, candied fruits and jams, valuable essential oils and various essences, which are widely used in the food, confectionery and perfume industries. Purpose. Citrus plants are currently mainly used for indoor and office landscaping, conservatories and greenhouses as ornamental rather than fruit plants. For the development of production for the cultivation of citrus crops as fruit, in industrial volumes requires high-quality available planting material in large quantities. Our goal was to investigate the available substrates for grafting citrus crops: peat, sand, coconut substrate, vermiculite, peat with sand, coconut substrate with vermiculite for rooting cuttings of citrus plants in protected soil. Methods. To obtain planting material used the method of propagation of citrus plants by green cuttings in a protected soil. Results. According to the results of studies on the rooting of citrus cuttings obtained the following results. The highest survival rates of Pavlovsky lemon, Washington Navel orange and Cavanaugh Vaso mandarin occurred in coconut substrate with the addition of vermiculite (85-98\%). Planting material obtained by green grafting using coconut substrate with the addition of vermiculite and vermiculite in a greenhouse in the village of Radensk, Oleshkivskyi district, Kherson region, showed a high result. engraftment compared to peat and sand. Conclusions. The conducted research makes it possible to recommend for further use in the production of citrus cuttings coconut mass substrate with the addition of vermiculite and vermiculite for protected soil.

Key words: cultivation, citrus plants, protected soil, varieties, green cuttings. 